\title{
Cerdà and Barcelona: The need for a new city and service provision
}

This paper examines Ildefons Cerdàs 1860 Plan for the Urban Expansion of Barcelona; specifically, how and why it was conceived in a unique way, in which the provision of services to the population was an important part. Cerdà based his expansion proposal on an in-depth socio-statistical study of old Barcelona's population conditions. The high mortality rates of the working-class population and poor health and education conditions pushed Cerdà to design a new type of urban planning, which he defined as "urbanism". In his proposal for the new city, he planned the location of services such as marketplaces, schools and hospitals. The first part of this paper introduces the urban and political preconditions of Barcelona and the statistics on which Cerdà based his contribution. The second part uses location theory and a geographic information system (GIS) to analyse the pattern of location and the population served by markets and hospitals. In addition, topographic maps from 1926 and 1975 are used to study the development of the expansion up to when it was fully developed. The evolution of the city differed from Cerdàs proposal, partly due to unexpected increases in population density, the built environment, and higher amounts of building occupation. Nevertheless, Cerdàs layout of streets and avenues has prevailed.

Keywords: urban planning, location theory, optimisation, wellbeing, GIS, spatial decision support system 


\section{Introduction}

This paper examines Ildefons Cerdàs 1860 Plan for the Urban Expansion of Barcelona; specifically, how and why it was conceived in a unique way, in which the provision of services to the population was an important part. Cerdà based his expansion proposal on an in-depth socio-statistical study of old Barcelona's population conditions. The high mortality rates of the working-class population and poor health and education conditions pushed Cerdà to design a new type of urban planning, which he defined as "urbanism", in which his main objectives were to obtain a high degree of wellbeing for the population through rational housing conditions and provision of services. In his proposal for the new city, he planned the location of services such as marketplaces, schools and hospitals. The first part of this paper introduces the urban and political preconditions of Barcelona and the statistics on which Cerdà based his contribution. The second part uses location theory and a geographic information system (GIS) to analyse the pattern of location and the population served by markets and hospitals. In addition, topographic maps from 1926 and 1975 are used to study the development of the expansion up to when it was fully developed. The evolution of Barcelona through history differed from Cerdàs proposal, partly due to unexpected increases in population density, larger percentages of land use and higher amounts of building occupation. Nevertheless, Cerdăs layout of streets and avenues has prevailed. Moreover, more recent plans for urban expansion and restructuring of the city have been in line with Cerdàs ideas. This paper postulates that urban planning is an important factor for quality of life and wellbeing. The city proposed by Cerdà was a response to the needs of Barcelona's population living inside the city walls. After the plan was approved, the evolution of the city was modified and adjusted to fulfil specific economic profits more than to respond to social needs.

An appropriate urban fabric can transform the liveability of a place. The population's level of wellbeing depends on the capacity of service provision, which is uneven across space. Education and health provision are related to population income differences. Urban planning can provide mechanisms of resource distribution and increased spatial justice (Smith, 1977; Soja, 2010). In line with these ideas, the issue at the heart of this paper is how urban planning containing the necessary services for the population can be used as a tool to redistribute wellbeing among the population. This paper endeavours to answer this question by studying, first of all, the preconditions of old Barcelona at the end of the nineteenth century with very little service provision and inadequate housing conditions for its population needs; and, in contrast, the proposed city planning, which had a group of services-to-population embedded in its layout. The optimality and rationality underlining the location of urban services in Cerdàs proposal has yet to be analysed; this is carried out in the second part of this paper, in which we ascertain some determining factors involved in locating facilities in order to balance social wellbeing and quality of life.

In 2010, the motto for the Shanghai World Expo was "Better City, Better Life". Policymakers and institutions focused their concerns on the urban population because more people live in cities than in any other type of location in the world. In 2050 the population in cities will have grown to about $70 \%$ of the total world population (United Nations, 2010). The challenge for current cities tests their capacity to provide a good quality of life for their population. Cities have two sides. Urban agglomerations are important in that they create economic spaces where knowledge and wealth are generated and businesses are attracted and kept (De Blij, 2009; Glaeser, 2011). Otherwise, in order to create good city elements, disagglomeration economies must be resolved.

Cities and the form that settlements take are important within many disciplines. Cities are potential alternatives for social organisation and institutionalisation (Le Galès, 2002). In a shrinking political landscape, cities are potential alternative structures to states and regions, where groups and institutions can be organised. Cities are changing rapidly, and a good way to make progress is to understand their past in order to construct their future. In this regard, evaluating the normative urban actions that have changed people's way of life can contribute to building better urban environments.

A broad variety of models have been generated for urban environments and quality of life. These range from highly theoretical models to empirical-explorative models stemming from different disciplines (Kamp et al., 2003). Urban policies developing quality of life focus on the relationship between people and their everyday urban environments (Pacione, 2003). Urban environment problems are multidimensional, stemming from private and public agents, economic circumstances and environmental conditions. Attempts to address these problems are also multifaceted, operating at a variety of urban scales and across all dimensions of life quality. Various disciplines approach urban problem-solving by exploring various components of quality of life, and identify strategies to solve specific problems in socio-spatial contexts.

Spatial disciplines specialise in how land-use patterns, density, property values and political fragmentation affect the cost of services (Carruthers \& Ulfarsson, 2003). Increasing social wellbeing in cities might commence with a social and territorial diagnosis, followed by adjusting urban policies to the population's needs. Wellbeing varies with location, and 
maps indicate which part of the population enjoys this, and where (Smith, 1973; Coates et al., 1977). For instance, if clean air is considered important for health, a map showing exposure to air pollution would be decisive in deciding where to live. Exposure to air pollution decreases as the distance from the city centre increases. Residential quality is directly related to the way people live. Geographies of income per capita, traffic congestion, crime, access to public parks or public spending on education are useful elements for analysing the dimensions of wellbeing. Therefore, decision-making processes about where to locate services are crucial in any society.

Wellbeing is not a simple concept. Many factors affect it and where it occurs. Geographically, welfare differences often exhibit considerable order and regularities. Wellbeing varies between neighbourhoods, usually related to income levels, and between developed and developing nations. Individual location decisions depend on wellbeing factors such as type of neighbourhood, safety, friendliness and sociability of neighbours and whether an individual's children have good friends living nearby. Individual welfare is therefore also affected by decisions made by other residents (Cox, 1979) and by other factors, such as what type of housing has been built and the characteristics of services located in that neighbourhood.

Location theory (Lloyd \& Dicken, 1972; Conkling \& Yeates, 1976; Dicken, 1976; Osleeb \& Ratick, 1990; Moreno, 1995) also provides explanations of industrial, migration, retail and residential location (Tiebout, 1956; Krugman, 1998; Davis \& Weinstein, 2002; Levy, 2004). Advantages and disadvantages, efficiency, type of activity and characteristics of the population are included in the decision process about location. Planning an efficient service distribution that facilitates access to jobs, education and health services would be factors to increase "spatial justice" (Soja, 2010). An efficient policy-planning strategy for services would provide equity in accessibility and reduce overcrowding, contributing to increased spatial justice.

Specifically, this paper uses a $p$-median model (Hakimi, 1964) to analyse how service areas are formed around a group of facilities. The $p$-median model seeks to locate a fixed number of facilities minimising the aggregate distance-time of the population receiving the service. These problems are considered "travel to get a good". We assume that these types of services are public goods. The factor space gives a public good a difference in availability; that is, individual service consumption will decrease as distance to the facility increases. Assuming all consumers have an equal utility function, their level of consumption of the good is directly proportional to the distance they have to travel to obtain the good.

\section{A case study: The Cerdà plan for the urban expansion of Barcelona and its evolution}

The Cerdà plan for the expansion of Barcelona has captured the interest of architects, urban planners, geographers and historians for decades. Nevertheless, little research has been carried out on studying the optimality and rationality underlining the location decisions regarding urban services within the Cerdà plan (Pallares-Barbera, 1986, 2005). Cerdàs diagnosis began by studying the living conditions of the population in the social structure of old Barcelona. His proposal for urban expansion was based on improving the population's living conditions. Therefore, he planned a rational distribution of basic services to the population. Schools, markets and hospitals were proposed in order to meet the educational, shopping and health needs of this population.

Barcelona's urban landscape has been shaped by political struggles, civil society and its geographic location. Situated in a valley on the Mediterranean coast, and surrounded by two hills, Montjuïc and Tibidabo, and two rivers, the Besòs and the Llobregat, Barcelona evolved into its full structure from the end of the nineteenth century through mainly the first half of the twentieth century. In the twenty-first century, the city is made up of four main parts, one being the medieval Ciutat Vella 'Old City'. Another section is the Eixample 'Expansion', a residential and service area designed by Cerdà. The third part consists of the old villages scattered across the valley, which became part of the city in the twentieth century and largely developed during the 1960s and 1970s. Finally, the fourth part is new neighbourhoods redeveloped for major events, such as the Olympics in 1992 and the Forum de les Cultures in 2004, from the mid-1980s to the present.

Nineteenth-century Barcelona was an industrial society and was active in trade through the port, historically connected to all other Mediterranean ports with goods and passenger traffic. The industrial revolution involved a huge densification of the urban fabric in which the bourgeois society, working class and factories were brought together in a walled medieval city. Then the quality of living conditions in the city decreased, with a high population density (856 inhabitants per hectare, when Paris had fewer than 400 in comparison), high-density housing for the working class (10 square metres per person), a poor drinking-water supply and a poor sewerage system. In 1834, 1854, 1864 and 1870 epidemics broke out, and 3\% of the population died each time. The average life expectancy was 38.83 and 19.68 years for the wealthier and poorer class- 
es, respectively (males' average from 1837 and 1847; Cerdà, 1867). In 1854, the Old City had the same dimensions as in the fourteenth century, and contained 200 streets less than 3 metres wide and 400 less than 6 metres wide. Urban expansion was prevented by the medieval wall, which was built and maintained for political reasons. The walls of Barcelona surrounded the entire city and were a sort of stone border between Barcelona and the rest of the world (Aibar \& Bijker, 1997). Between 1854 and 1868 the contested walls were demolished; which opened up the possibility of urban expansion toward the surrounding countryside. To plan the urban growth, in 1859 the council held a contest for an urban project to link the city's medieval core to the surrounding villages. After considering various projects, the council chose the plan by Antoni Rovira, the council's chief architect. However, in a surprising intervention by the Spanish government, the recently created Ministry of Public Works in Madrid ordered the municipality to implement Ildefons Cerdàs plan. ${ }^{[1]}$

Ildefons Cerdà i Sunyer (1815-1876), the son of wealthy rural parents from a tiny town north of Barcelona, studied engineering in Madrid (Estapé, 1968-1971). ${ }^{[2]}$ He travelled widely around Europe and discovered technological innovations applied to industry and to means of communication. These ideas influenced his urban-planning concepts. Upon his return to Barcelona, his general beliefs were to understand how "social order" had to be embedded in an urban development, where movement, communication and technology had to be the basis for a new city (Figure 1). Cerdăs exhaustive diagnosis of urban dynamics and the statistics of the living conditions of the working class ${ }^{[3]}$ (Cerdà, 1867) were the pillars for his Barcelona expansion proposal.

His detailed description of the population's professions (tailors, shoemakers, cooks and merchants) and building functions (convents, palaces, warehouses, mills and charitable institutions [Span. casas de beneficiencia]; Cerdà, 1867) does not include schools, teachers, physicians or hospitals. The lack of such services, or at least their very low influence on society,

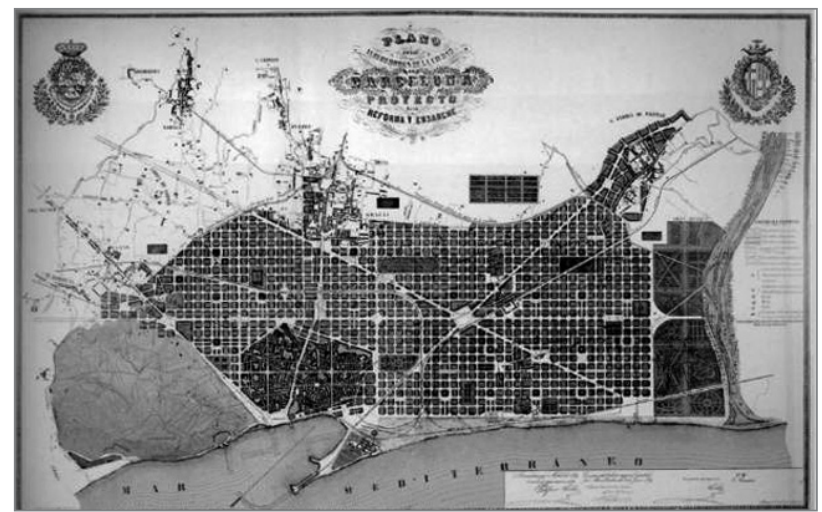

Figure 1: Cerdà's 1861 Map for the Urban Expansion of Barcelona (source: Cerdà, 1861). resulted in a scenario in which high mortality rates and children employed in factories, instead of attending school, were common in general daily life.

\subsection{Cerdà's "foundation" for a new city}

Cerdà's "social philosophy" (Cerdà, 1844, 1867) focused on his "urbanisation idea". In order to conceptualise urbanism, he studied the origins of urban forms and wrote up his findings in two volumes (Cerdà, 1849). He developed a theory about the scientific and modern organisation of urban form. His model included the effects of the epoch's new technology on urban forms: the railroad, streetlights, the telegraph, and sewers. In 1854, he did not use the word "expansion" for his plan; he talked instead of the "foundation" for a new city. Regularity was a main feature, with an unlimited geometrical grid of perpendicular intersections in the streets. His main objective in implementing the grid form was to avoid privileged zones for social classes and to achieve "optimal hygienic density" (Solà-Morales, 1991). His leitmotif was to achieve optimal living standards of 6 cubic metres per person and room, and 40 square metres per person in housing (or, as he wrote, 40 square metres per person within towns): "Nowadays, one would need 6 cubic metres of atmospheric air per person and per hour in order to breathe correctly. ... Scientific studies establish a minimum of 40 square metres per person within towns" (Cerdà, 1859: 64).

He produced various documents on "scientific" urbanisation, which included statistics about the working class, his 1861 map and the First-Draft Document for Barcelona's Expansion (Span. Memoria del Ante-Proyecto del Ensanche de Barcelona). For Cerdà, the possibility of a substantial improvement of the conditions of urban life would involve solving two questions: first, how building new roads, sanitary infrastructure and municipal equipment could be financed and, second, how housing prices could be adjusted to different wages (Soria y Puig, 1991). Three of his main concepts were used to determine the side length of the blocks (113.3 metres): the number of square metres per person, the number of inhabitants per house and the width of streets (Cerdà, 1861).

$x=\frac{2 p v-2 b d}{d} \pm \sqrt{\frac{4 p v}{d^{2}}}\left(p v f-2 b d f-b^{2} d-d f^{2}\right)$

Where

$x$ is the length of the side of the block;

$p$ is the number of square metres per person;

$v$ is the number of inhabitants per house;

$b$ is the width of the street;

$d$ is the height of the facade; and

$f$ is the depth of the building site. 
Without an explanatory interpretation, Cerdà took the values of the variables to be $2 b=20$ metres, $f=20$ metres, $d=$ 20 metres, $v=43$ and $p=40$, obtaining 113.3 metres, the current side length of the block.

The plan proposed incorporating an additional 1,969 hectares to a medieval core of only 192 hectares by implementing a grid of streets between the Old City and the peripheral villages. The grid consisted of 1,000 blocks, 113.3 metres by 113.3 metres in length and width, with streets measuring 20 to 30 metres wide. Like a compact garden-city model, the grid had two parallel buildings on each block, from 10 metres to 20 metres deep (building occupation: $40 \%$ of total block), with yards and green spaces in between each block, intertwined with pedestrian paths in the middle that linked the inner open spaces together independent of the street network. Furthermore, the corners of each block were cut at $45^{\circ}$ angles, 20 metres long, to create small squares between the octagonal blocks (Figure 2).

The map's legend contained 33 schools, three hospitals located on the edge of the city for hygienic conditions, eight parks, 10 markets and 12 administrative buildings. Adopting and implementing his plan, with amendments and modifications, Barcelona became a modern city and a model for other cities (Cerdà, 1861). Inspired by the diagnosis of the territory, Cerdà redefined urban strategies and adjusted them to the scale of the metropolis. His timeless idea was the foundation for many projects that followed in twentieth- and twenty-first-century Barcelona. ${ }^{[4]}$

\subsection{Implementation of Cerdà's plan}

After the plan was approved, council ordinances immediately modified the plan. Real-estate investment became attractive to developers, who, with land speculation and the freedom to introduce modifications, could triple their investments in a 4 -year period. The first modification allowed a 100\% increase in the construction area, converting the parallel-building design into a fully built block with open space in the inside. The council's policy allowed automatic rezoning of rural land into
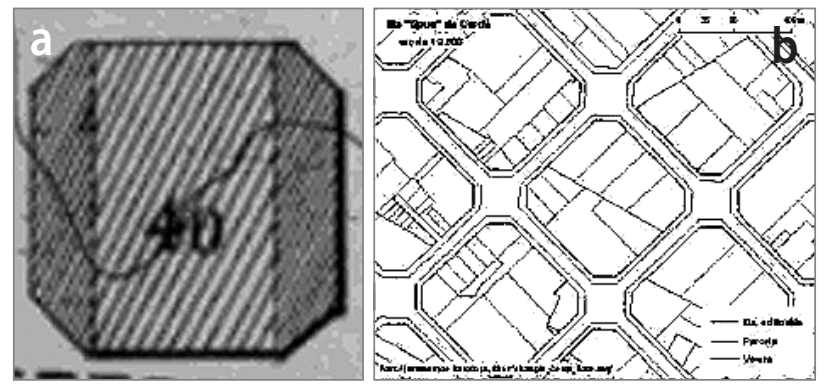

Figure 2: a) Block with housing built on two of the sides; b) Corners, squares and octagonal forms (source: a: Cerdà, 1861, b: Barcelona City Council, 2011). urban land. In the first 20 years after the approval of the plan, only 100 hectares were built. It took a quarter of a century for this area to double. By $1872,90 \%$ of the newly constructed housing did not comply with Cerdàs guidelines (Casellas, 2009). Over time, new council ordinances would further modify the plan and increase construction densities:

The average width of the streets was reduced from 35 metres to 20 to 30 metres; the explicit concern with special housing facilities for workers, as a means of achieving a more egalitarian city, was completely abandoned; the depth of buildings was extended to 20 metres in all cases; and the former regular distribution of parks $(82.35 \mathrm{hec}-$ tares) and public facilities was not made obligatory. (Busquets Grau et al., 1992)

As early as 1890 , buildings occupied $70 \%$ of the block area on average, instead of the original $50 \%$. The situation was exacerbated by successive building bylaws, and in 1958 the building volume of the block, which according to Cerdäs bylaws should not exceed 67,200 cubic metres, reached 294,771.63 cubic metres. (Aibar \& Bijker, 1997)

The evolution of the plan was different from what Cerdà had anticipated. Cerdà calculated how many hectares the population living within the city walls needed to settle in the new premises of the expansion. Seven municipalities ${ }^{[5]}$ surrounded the Barcelona Valley. The expansion had to take place in the plain between the Old City and these municipalities (Figure 3). Between 1855 and 1860, the total population of these eight urban concentrations was 249,209 (Statistical Institute of Catalonia, 2011), among which the highest-percentage agglomerates were within the Old City. Apart from tiny urban concentrations, ${ }^{[6]}$ the Barcelona Valley was an agricultural space filled with orchards and vineyards connected by rural routes to the Old City, where the marketplace and the

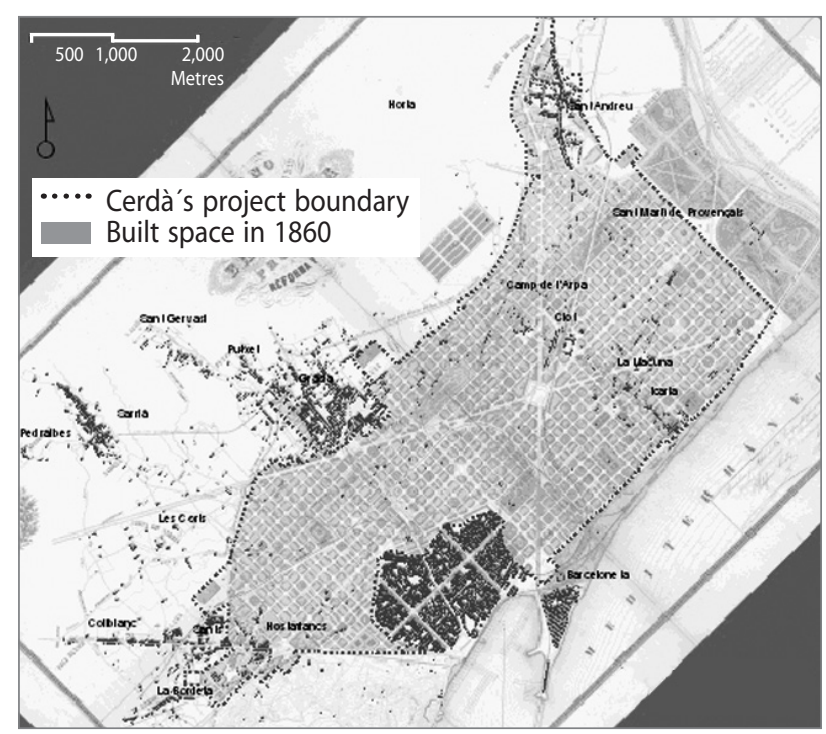

Figure 3: The Old City of Barcelona, neighbouring towns and the 1860 expansion proposal (source: Cerdà, 1860). 


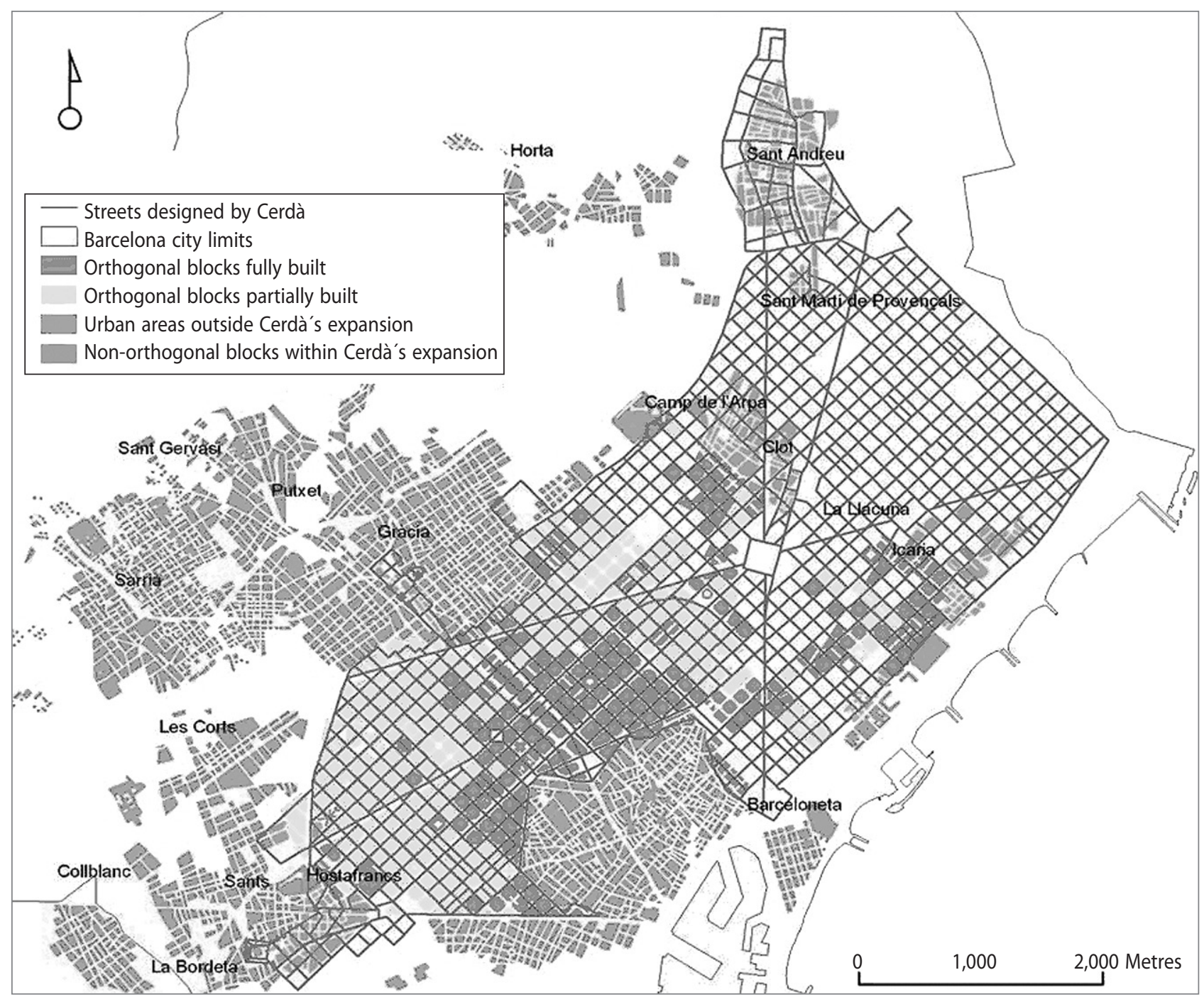

Figure 4: Barcelona's built environment in 1926 (source: National Geographic Institute, 1926).

port were located. By 1926, the national topographic map of Spain (Span. Mapa Topográfico Nacional de España) showed the urban space scattered across the plain and some of Cerdàs block morphology built and streets delineated (Figure 4).

Urban development grew rapidly during the first quarter of the twentieth century. Within the projected expansion, 910 blocks were already fully or partially built (628.2 hectares). Outside the expansion, the neighbouring municipalities ${ }^{[7]}$ expanded greatly, with 2,070 urban blocks built in 722.2 hectares. The differences between both developments are evident in the different land area occupied by the blocks. These two urban processes have interesting implications related to which social classes occupied each type of building and what the housing prices were, which are beyond the scope of this paper. The population grew during the first decades of the twentieth century, with 721,869 inhabitants in 1920 and 1,005,565 in 1930 (Statistical Institute of Catalonia, 2011). The early buildings in the expansion were concentrated in the most emblematic newly-built streets such as Passeig de Gràcia, Passeig de
Sant Joan and Urgell, where the bourgeoisie hired prestigious architects (Gaudí, Domènec \& Montaner, and Puig \& Cadafalch) to build their elegant homes.

By 1951, 1,201 blocks in 814.4 hectares of Cerdäs expansion had already been developed, and Barcelona as a whole had a population of 1,280,179 (National Geographic Institute, 1951; Statistical Institute of Catalonia, 2011). From 1950 to 1960, the Expansion section suffered a drastic deterioration. The council did not have a maintenance or restoration policy, and many Modernist structures were demolished. Furthermore, new additional floors built with cheap materials were added on top of nineteenth-century buildings, with absolute disregard for the structural design of the buildings. The inner courtyards that Cerdà designed as open spaces were further converted into storage rooms and garages. Over time, the total built area of a block changed from the 13,520 square metres allowed under the first ordinances, approved in the 1880s, to the 101,497 square metres allowed by Mayor Josep Maria de Porcioles in the 1960s (Casellas, 2009). In 1977, 1,464 


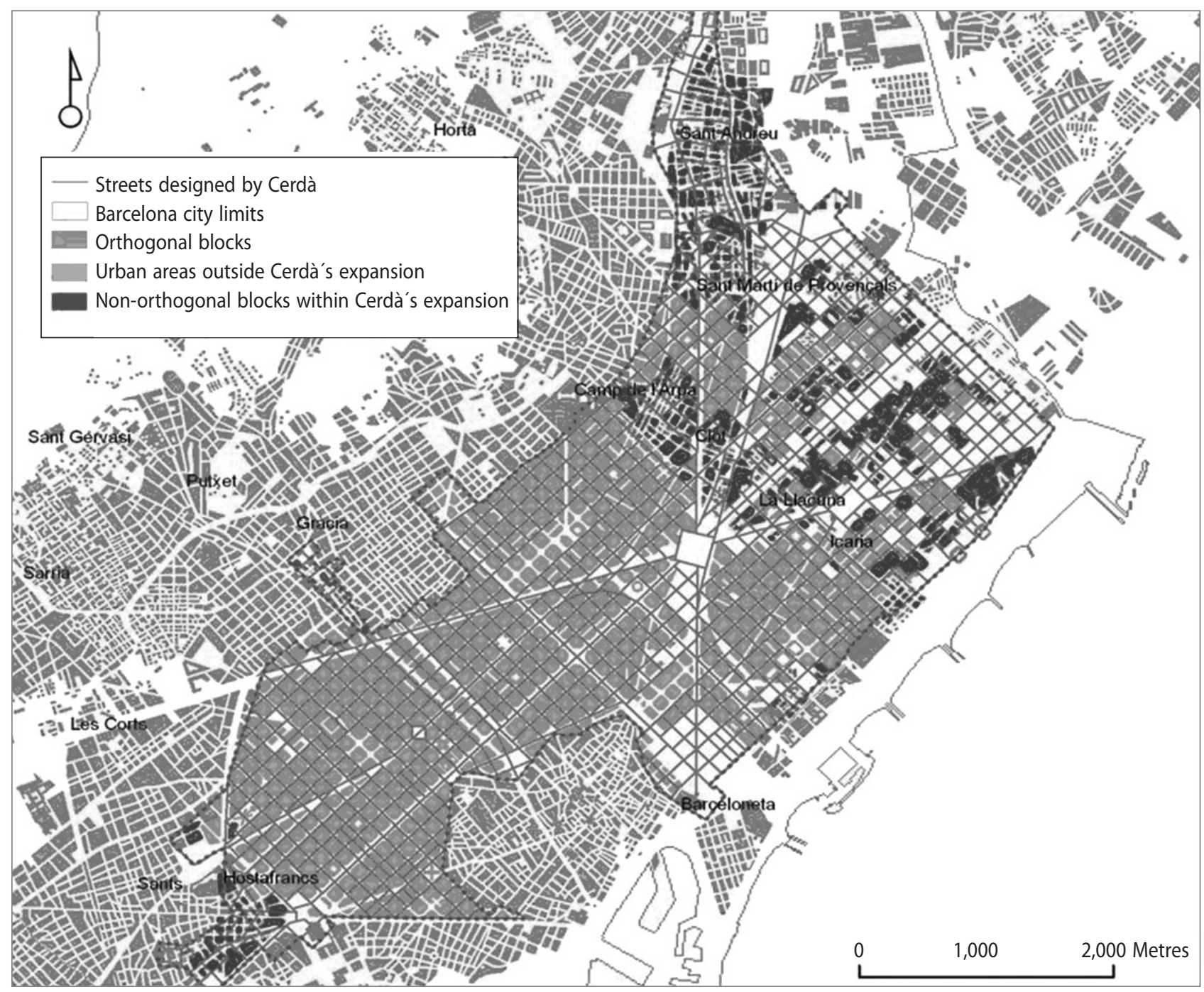

Figure 5: Barcelona's built environment in 1977 (source: National Geographic Institute, 1977).

blocks in 932 hectares of Cerdäs expansion ${ }^{[8]}$ had already been developed, and Barcelona as a whole had a population of 1,754,714 (Statistical Institute of Catalonia, 2011; Figure 5). Economic development attracted people from other parts of Spain and Barcelona's metropolitan area was developed.

\section{Methodology}

This methodology focuses on determining the optimality and sense of efficiency that the location of facilities in the Expansion section had, but that Cerdà never explained. At the same time, as his background suggested and as described above, his sense of efficiency was intended to improve the social wellbeing of the population, which was scant within the Old City. Cerdà attributed the causes of mortality and poor urban conditions to greed and ignorance: "The errors in the lack of hygienic means in founding a city are a consequence of ignorance and greed and prevent the development of robust, wise and industrious generations. These errors increase mortality, decrease the average life expectancy and primarily contribute to epidemic attacks every twenty years" (Cerdà, 1860: 55). Under these beliefs, his plan had to be built using new standards of the (new) culture of the (new) century "[ $\mathrm{t}$ ]o attain the good conditions that the culture of our time demands for the entire population" (Cerdà, 1860: 56).

To carefully capture the meanings of Cerdàs service locations and why he decided to plan them in a regular pattern, scattered across Barcelona, this section of the article analyses the main variables of his implicit model. Although the need for services for the population was explicitly stated in the plan's proposal, the methodology behind the service pattern was not explained. In the map, the distribution of markets and health, education and social services can give a sense of Cerdàs idea of social equality. For him, urbanism was a tool to diminish the differences in the living conditions of the various social classes, particularly in Old Barcelona. The population's health and education achieved through service provision throughout 
the urban network introduced a perception of a modern way of living. Then, his proposal implied regularly distributing basic services throughout the Expansion section. Of all these services, two services - markets and hospitals - are analysed in this paper, and the mathematical model and its implementation is suggested.

Optimality and location have primarily been studied in location theory as a means of making decisions and obtaining efficient urban planning. In addition, spatial optimisation models that use GIS as a tool to solve location problems (Church, 1999, 2002; Cromley \& Hanink, 1999; Malczewski, 1999) make it possible to efficiently distribute urban space, study the compatibility of adjacent uses, and plan the location of different but complementary urban land uses adjacent to one another (Ligmann-Zielinska \& Jankowski, 2007; Church \& Jankowski, 2008). One of the functions is to locate complementary and compatible functions together such as schools and housing, or shops and banks; however, in contrast, polluting industry and housing would be considered incompatible uses, and their adjacent location would therefore be restricted. "Unwanted activities" (Bosque \& Moreno, 2004) such as incinerators or nuclear waste dumps have very strict restrictions for adjacent use compatibility and distance in location models. Optimisation modelling is a generative technique that allows multiple scenario analysis, in which the outcomes obtained are non-inferior (Pareto-optimal) to the objectives contained in the model. It involves testing and analysing the optimal and suboptimal objectives and generating a number of compromised spatial solutions that can be both feasible and different from one another. The optimal solution will be that which minimises the aggregate distance.

Within the theory of location of public facilities, the $p$-median model (Hakimi, 1964) aims to locate a fixed number of facilities, so that the average distance or time that users take to reach them is minimised. The basic constraint is that there is a fixed budget for the system of facilities and that all facilities have the same "investment" (per facility) and "expansion" (per user) cost. Following this background, the methodology in this paper consists of two separate parts: first, the spatial optimisation model itself is proposed and explained and, second, the implementation used to test this model in Cerdàs plan is explained, analysed and evaluated, and the results are discussed.

\subsection{The optimisation model}

The p-median model is a two-objective model; one of the objectives is to minimise aggregate travel time between a population node and a group of facilities $(p)$, and the other is to find the distance that separates users from their nearest facility (Narula et al., 1977). In these consumer-oriented loca- tion problems, consumers must travel to obtain the good - as opposed to, for instance, fire engines and ambulances, in which the service is "delivered" to consumers (Park, 1983).

In the objective function, we want to minimise the distance the population has to travel to obtain the service, subject to constraints that ensure that all users receive the service, that the service is provided by only one facility, that the service is provided by facilities that are open and that the total number of facilities is not exceeded. In order to attain this result, the decision variable of this model is $x_{i j^{\prime}}$

General model:

Given

$$
\left\{a_{i}\right\}_{\mathrm{i}=1}^{n} \quad\left\{d_{i, j}\right\}_{\mathrm{i}, j=1}^{n}
$$

Choose

$$
\left\{y_{j}\right\}_{j=1}^{n} \quad\left\{x_{i, j}\right\}_{i, j=1}^{n}
$$

Where

$$
\begin{aligned}
& y_{j} \in\{0,1\} \\
& x_{i j} \in\{0,1\}
\end{aligned}
$$

In order to minimize $\mathrm{Z}$ equal to

$$
\sum_{i=1}^{n} \sum_{j=1}^{n} a_{i} d_{i j} y_{j} x_{i j}
$$

Subject to

$$
\begin{aligned}
& \sum_{j=1}^{n} y_{j}=p \\
& \sum_{j}^{n} y_{j} x_{i j}=1, \forall i
\end{aligned}
$$

Where:

$a_{i}=$ the quantity of the population in node $i$;

$i=$ the origin of the population;

$j=$ the destination of the population;

$n=$ the number of nodes;

$d_{i j}=$ the shortest distance berween node $i$ and node $j$;

$y_{j}=$ the possible location of services;

$p=$ the number of services;

$x_{i j}=1$, if the population of node $i$ is assigned to $j, 0$ otherwise;

$y_{j}=1$, if the service is located to $j, 0$ otherwise.

We impose some assumptions that can be relaxed in future analysis: 
1. There is no heterogeneity regarding income levels; we have a utilitarian social welfare function, in which the objective function places the same weight on all individuals. Hence, income differences are ignored.

2. There is no congestion in service capacity.

3. There is homogeneity in product and quality.

In this paper, the implementation of this model is carried out assuming a set of known locations. The population in each node $j$, where the facility is located, is null. The results obtained can be suboptimal locations because the general model is not solved; that is, in the general model the specific location of services would be unknown (not given). However, the specific location nodes would be the result of solving the general location-allocation model. The optimal location would be that which has the minimum aggregate distance to services.

\subsection{Implementation of the model in GIS}

Part of the use of GIS is the spatial and alphanumerical information with which we implement the model. In this particular case, the main difficulty lies in the fact that we are working from an image that is a proposal for the organisation of Barcelona's structure. It is a drawing of the expansion made by Cerdà, which must be geo-referenced so that it can be incorporated into the GIS. Because it is a proposal, current coor- dinates must be identified on Cerdàs map in order to be able to geo-reference it. Cerdà identified a reference coordinate, the Clock Tower (Cat. Torre del Rellotge). With this point, and the two central axes of Barcelona, Meridian Avenue (Cat. Avinguda Meridiana) and Avenue of the Parallel (Cat. Avinguda del Parallel), a total of 25 points could be identified. The sequence that evolved in the georeferencing process using the GIS ArcMap was the following:

1. To move and rotate Cerdàs map so it can be placed on the axes of the current streets;

2. To place the central point of the Clock Tower of Cerdàs map on the same geo-referenced point of the axes of the current streets;

3. To identify up to 25 control points to carry out the geo-referencing process;

4. To carry out the geo-referencing process. The final root mean square (RMS) error was 1.79 .

\section{Spatial analysis of Cerdà's location pattern: Hospitals and markets}

The substantial idea at the root of Cerdàs proposal for designing a city for the new industrial era contained many elements of present-day cities; and in proposing this he was implicitly "scientifically" rejecting the old pattern implied by the city of

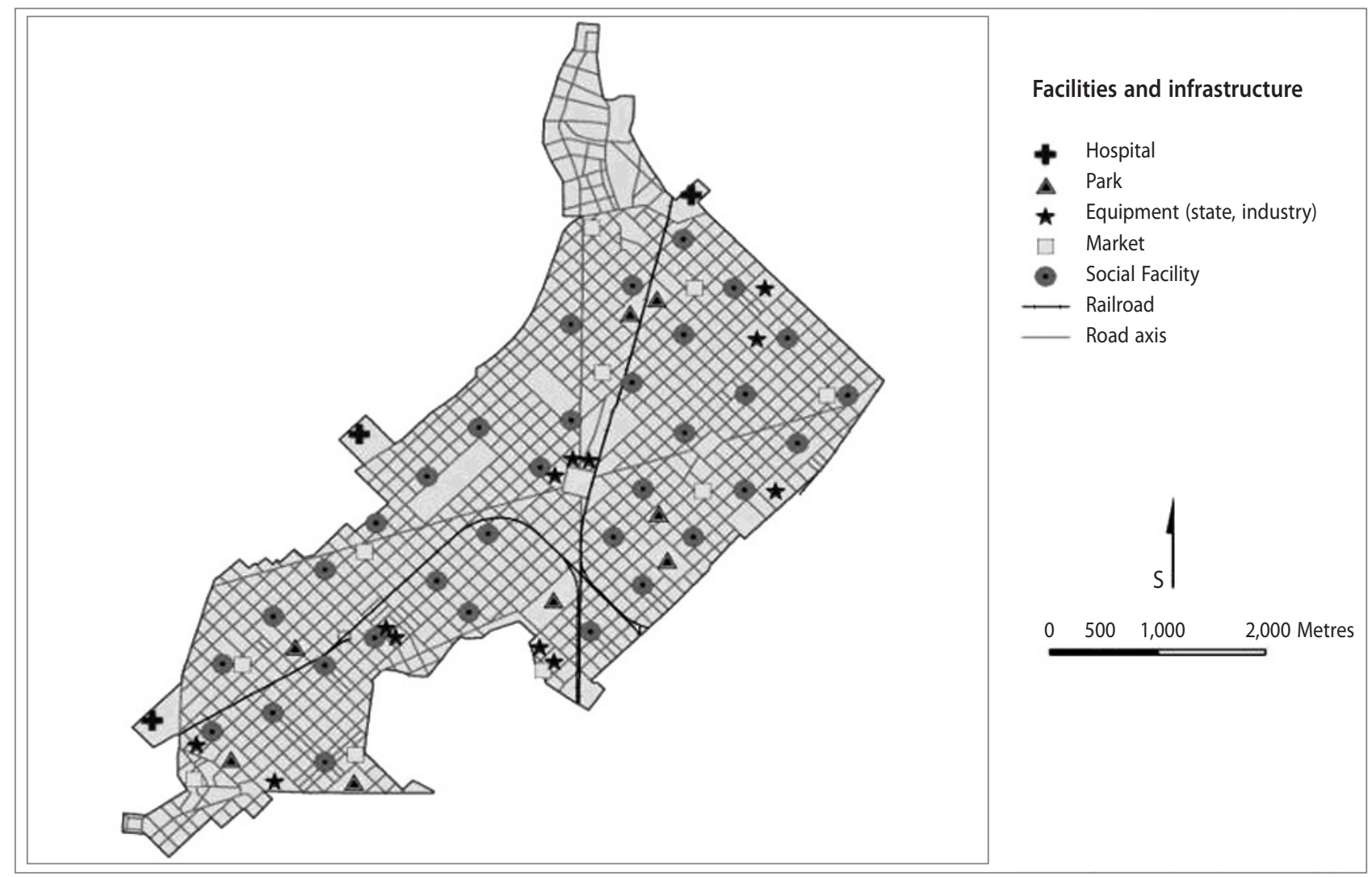

Figure 6: Cerdà's facility location pattern (source: Cerdà, 1861). 
Table 1: Population within each hospital service area.

\begin{tabular}{llll}
\hline Interval time in minutes & Population & $\%$ & Cumulative \% \\
\hline $1-9$ & 16,251 & 11.0 & 11.0 \\
\hline $10-19$ & 52,500 & 34.0 & 45.0 \\
\hline $20-30$ & 50,500 & 33.0 & 78.0 \\
\hline$>30$ & 33,224 & 22.0 & 100.0 \\
\hline Total & 152,475 & 100.0 & \\
\hline
\end{tabular}

\subsection{Data}

the industrial revolution. Improving urban living conditions by creating a plan of almost 2,000 hectares of square grids and available housing, and inserting elements of sanitary, educational and social amenities between housing and streets would at least partially satisfy his egalitarian goal. Almost 250,000 inhabitants (Statistical Institute of Catalonia, 2011) of the old Barcelona had to be evenly distributed in the new Barcelona and services had to be provided by 33 schools, three hospitals located on the edge of the city for hygienic conditions, eight parks, 10 markets and 12 administrative buildings. The regularity in the location distribution of facilities in the plan suggested the existence of some optimising criterion, in which the $p$-median model would provide answers by minimising the weighted distances to the facility located.
We based our analysis on the data found in Cerdàs urban plan documents, in which he proposed a density of 250 inhabitants per hectare and 40 square metres per person. The number of facilities and their locations is taken from the set that Cerdà planned in his map. The number of demand points is $926 \mathrm{cen}-$ troids. For the analysis, we considered the population centroid to be located in the centre of each block. The population in each demand point or centroid is calculated taking into account the parameters given by Cerdà, in relation to types of housing for different classes of the population; and assuming social classes are mixed in each block. Percentages of population per income level are calculated based on the proportion that the Barcelona census of 1856 gave regarding various professions and considering the percentage of construction

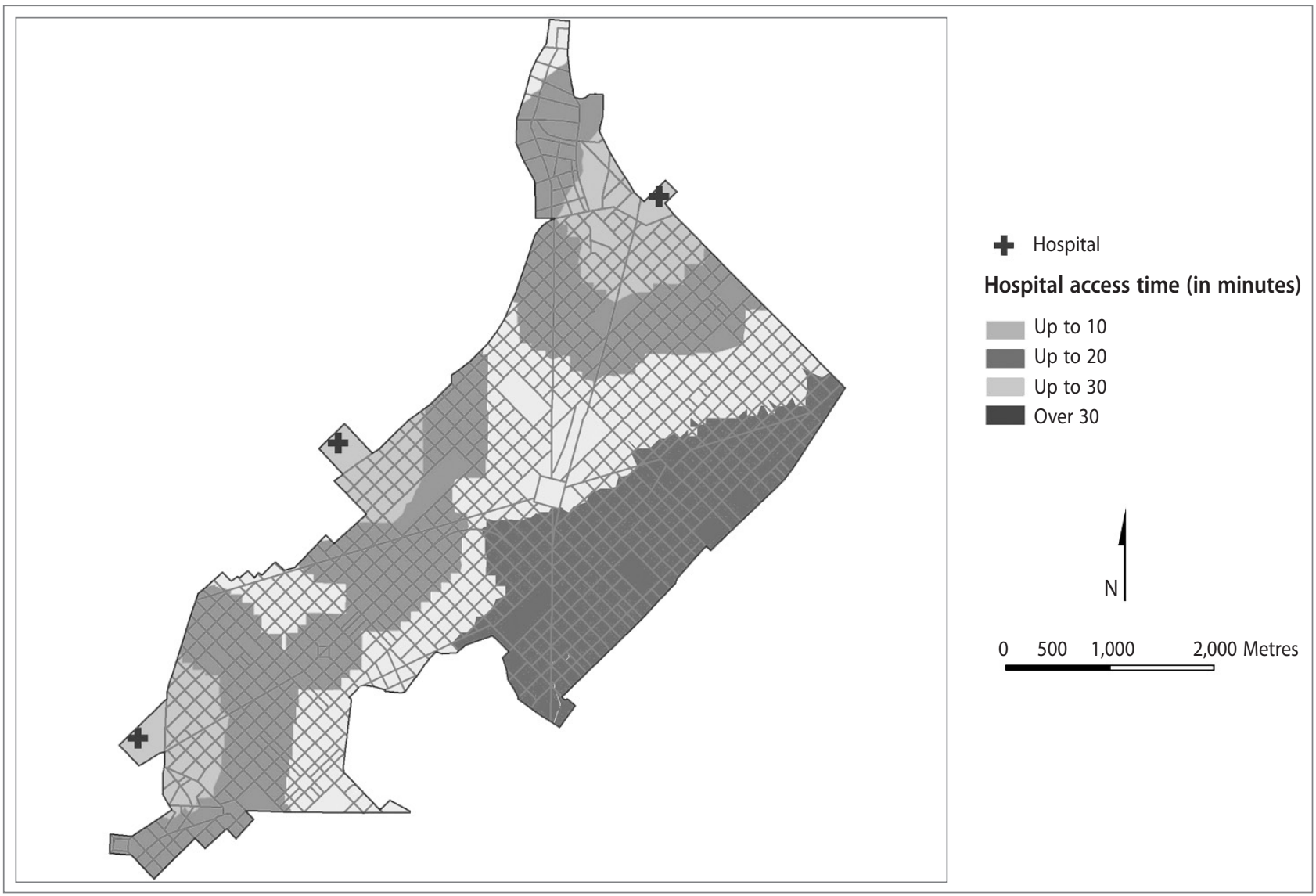

Figure 7: Spatial analysis: Hospital service areas (source: Cerdà, 1861; Cartographic Institute of Catalonia, 2006). 
Table 2: Population within each market service area.

\begin{tabular}{llll}
\hline Interval time in minutes & Population & $\%$ & Cumulative \% \\
\hline $1-5$ & 19,444 & 13.0 & 13.0 \\
\hline $6-11$ & 54,268 & 36.0 & 49.0 \\
\hline $12-24$ & 70,691 & 46.0 & 95.0 \\
\hline$>24$ & 8,072 & 5.0 & 100.0 \\
\hline Total & 152,475 & 100.0 & \\
\hline
\end{tabular}

allowed for each block taken from the 1860 map. The Old City is not included. There is no population in the facility points.

A large group of Cerdăs blocks in the grid have 12,370 square metres, but sometimes a block is twice as big or divided in half or in quarters, depending on the pattern of streets and avenues. Each person's travel time would be calculated from the centre of each block to its closest market or hospital. Distance is considered to be "Manhattan or $\mathrm{L}_{1}$ rectilinear" ${ }^{[9]}$ distance; that is, a person cannot travel diagonally between blocks, but must follow the assigned orthogonal pattern of streets. Streets are 113 metres long and 20 or 30 metres wide. Travel time for the population to obtain a service is assumed to be walking time, whereby a person is considered to walk 4 kilometres per hour.

\subsection{Analysis and discussion}

The group of facilities proposed in the map is parks, hospitals, schools, state facilities, markets and "social facilities" (Figure 6). In this paper we analyse the service areas of markets and hospitals using ArcGIS Spatial Analyst. Two variables entering into the analysis are facilities' location and population in demand points. The expected results would give the service area within a distance time away from the location facility and the population covered within this area. Introducing different intervals of time around the point where the facility is located into the analysis would give different scenarios in which a different proportion of population is served by a facility, and the maximum time this population must travel to reach the service. Further research, which is beyond the scope of this

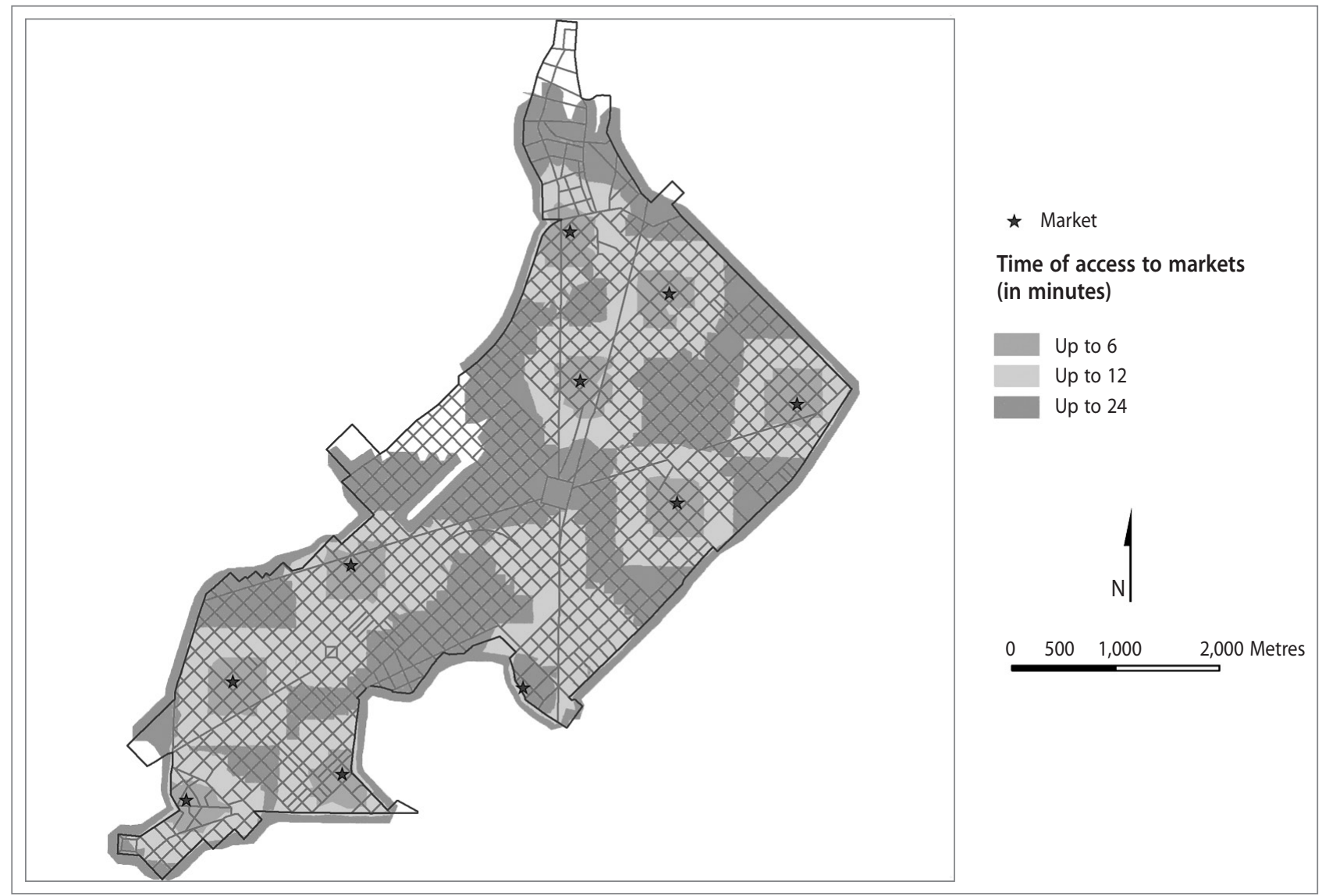

Figure 8: Spatial analysis: Marketplace service areas (source: Cerda, 1861; Cartographic Institute of Catalonia, 2006). 
paper, could be carried out in order to analyse the optimal location of schools and other services.

The implementation of the general $p$-median model is restricted in this analysis. Service area analysis differs from the general $p$-median model in that in the former the facility location is given, whereas in the latter the location allocation is a solution to the problem; that is, given a fixed number of facilities and given a set of points of demand, the optimal location of facilities would be the result of the problem-solving procedure. As regards hospitals, we consider a given set of three hospital locations - as in Cerdàs proposal (Figure 7). Service areas are constructed around each of the hospitals with the following travel distance intervals: 1 to 9 minutes, 10 to 19 minutes, 20 to 30 minutes and more than 30 minutes. In this scenario, for the four service areas displayed, $45 \%$ of the expansion proposal's population is covered within a 19-minute distance; and $78 \%$ within a scope of 30 minutes to a hospital (Table 1). Implicit assumptions are imposed, such as no traffic congestion, all people can walk and the capacity of each hospital is not saturated.

Comparing the average life expectancy inside the city walls of Barcelona between richer and poorer classes, which was 38.83 and 19.68 years, respectively (males, average from 1837 to 1847; Cerdà, 1867); with 10 midwives and 69 surgeons (Cerdà, 1867), and considering the direct relationship between the number of hospital beds and life expectancy, the proposed location of three hospitals near the population would increase their life expectancy enormously. Anachronistically, but for means of comparison, in 2009 the global low-income group life expectancy was 57 years, whereas the world high-income life expectancy was 80, and the life expectancy in Spain (2009) is 82 for both sexes in all income groups (World Health Organization, 2011).

With the objective of minimising the distance travelled to the nearest market, market service area analysis has similar restrictions as hospital service area analysis. Therefore, the walking population is assumed to move at 4 kilometres per hour and markets are assumed to not have the capacity for congestion. Market location and number are given according to Cerdàs map. The service areas constructed around each of the hospitals have the following travel distance intervals: 1 to 5 minutes, 6 to 11 minutes, 12 to 24 minutes and more than 24 minutes (Table 2). Within 24 minutes $94 \%$ of population is covered by a market (Figure 8). With three markets in the Old City, two of them fish markets (Pescadería del Mercado del Borne, 425 square metres, and Pescadería del Mercado de Isabel II, 900 square metres) and one of them for general groceries (Mercado de la Plaza de Isabel II, 3,525 square metres; Cerdà, 1867), the proposed increase to 10 markets would pro- vide better provision and diversity of goods to the population.

The structural question of this paper postulates that urbanism can be used as a tool for improving wellbeing. These findings reveal that, by imposing a regular pattern of markets and hospitals, the population is within walking distance from a service that can prevent illness and improve their health, or 30 minutes' walking distance from their basic needs for everyday nutrition. Other analysis could be done by increasing the population demand or the number of facilities, or by improving the capacity, which would have different results in service areas.

\section{Conclusion}

Today's Barcelona is the result of historical institutional policy-making, social movements and cultural phenomena; in addition, its twenty-first century morphology is a result of the massive urban-planning intervention that enlarged the city in the 1860s (Figure 9). Cerdà constructed a theory of how people should live, based on his social statistics for the working class, and on evaluating the needs of the entire population and the need to implement economic activity in a modern "futuristic" city. This paper evaluated the foundations of his "science"; however, much more remains to be done. His proposal changed the way in which people thought about urban space, and introduced the idea of changing people's behaviour by modifying public space. Part of his work was utopian, referring to a theoretical city, where it would be difficult to implement all the new and revolutionary elements that he thought had to be in a city. We worked under the hypothesis that "utopia" goes beyond reality but could contain the optimal objectives that must be attained in order to increase the population's wellbeing. Optimal objectives are like a framework; they contain standards and goals, reality escapes the optimal and usually suboptimal aims are not even achieved; however, the utopian standards are sown and the plant can grow inwards or outwards, and very tall. This is not the only one; other utopian urban models, such as Oscar Niemeyer's Brasilia, offered alternative solutions and a structure with which cities can be compared and with which they can experiment.

Cerdăs most important innovation was to create a new urban culture and to build a bridge between the urban roles and functions of a metropolis and a healthy population. Cerdà established the links of the city, which connect humanity and its structures. He put forward normative policy mechanisms for the urban era and inspired the city with embedded urban technologies and mechanisms of self-defence and self-protection. His model of innovations and new functions was a framework for the city's ability to generate the information needed to solve inner-city problems. 


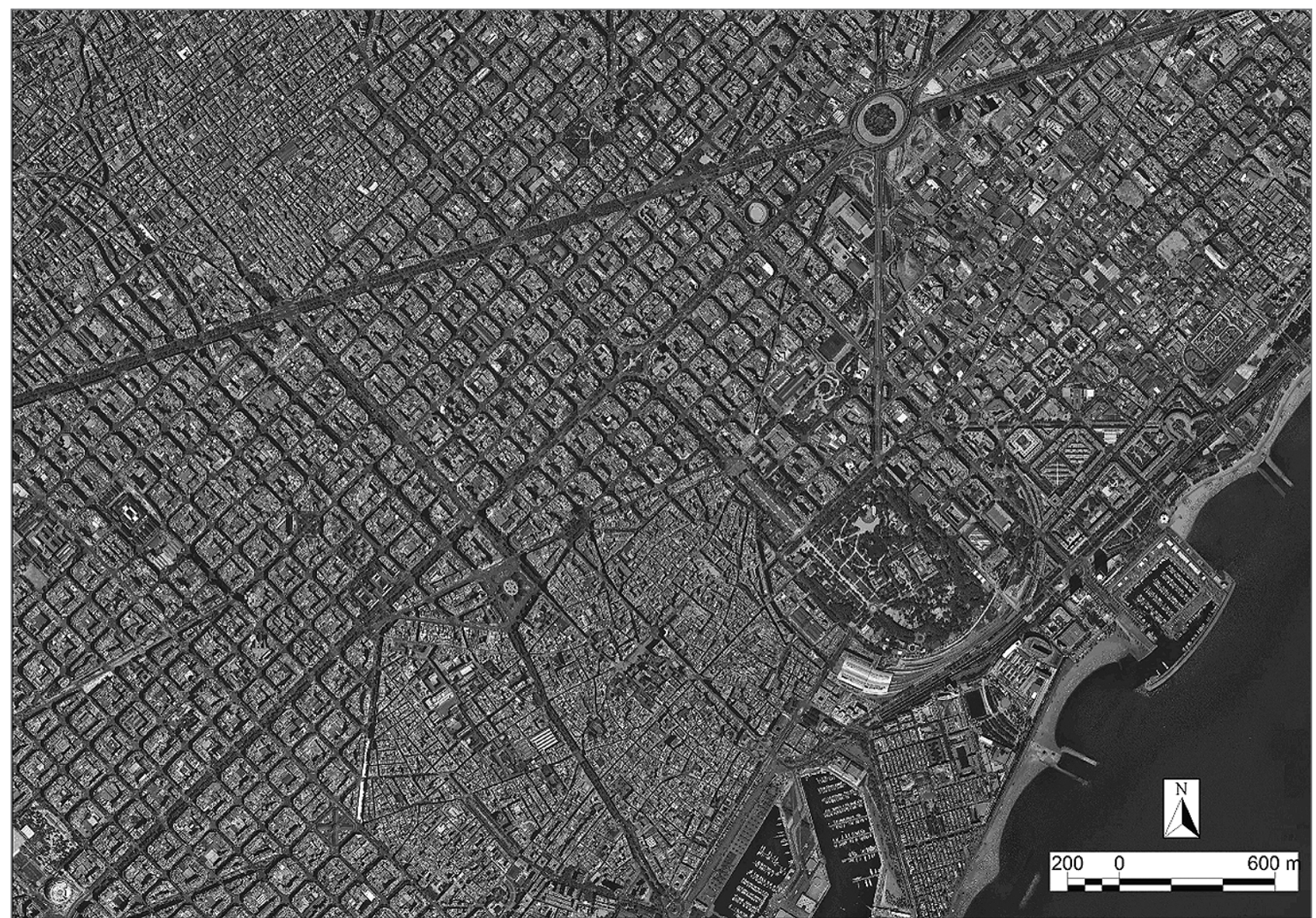

Figure 9: Orthophoto map of Barcelona (source: Cartographic Institute of Catalonia, 2010).

The structural question of this paper was to examine how good urban planning can be used to improve wellbeing. Assumptions have been made associating good health and good quality of life with service provision to improve wellbeing. We tested what level of the population was served by the location of hospitals and markets proposed by Cerdà, as opposed to the null provision in the Old City. Cerdàs idea of service efficiency was in part a solution stemming from common sense and from the progressive goal that the poor conditions of the working population could be improved through good urban planning. In this paper we worked with modern location theory models and GIS to analyse his results; in fact, service-area analysis of hospitals and markets has been useful for finding primary solutions to this problem. Specifically, and with restrictions to be relaxed in a future analysis, we have shown that $78 \%$ of Barcelona's Expansion section population has a hospital within 30 minutes' walking distance and $95 \%$ of the population is within a maximum of a 24-minute walk to a market. Many things can be achieved in future research. Most of these fall under the following proposals: considering facility location as an endogenous variable of the model, taking into account the capacity of services, introducing different population densities, introducing a different typology of services, individual decisions affecting wellbeing, a heterogeneous population, various levels of income, efficiency (minimising aggregate demand) and further discussing the spatial efficiency and wellbeing associated with service distribution.

Since the 1960s, Barcelona has expanded to become a metropolitan continuum where the transport infrastructure has contributed to its metropolitan area growth. After 152 years, Barcelona's services and population are very different from Cerdàs proposal. The idea evolved and today complexity makes any comparison very difficult. The population inside the Expansion section and in the old (and then incorporated) neighbouring towns makes up a large city where the urban planning provided by the original model has contained many complex processes that have resulted in contemporary Barcelona.

Montserrat Pallares-Barbera

Harvard University, Institute for Quantitative Social Sciences, Center for Geographic Analysis, Cambridge, Massachusetts, USA

Autonomous University of Barcelona, Geography Department,

Barcelona, Spain

E-mail: mpallares@cga.harvard.edu

\section{Anna Badia}

Autonomous University of Barcelona, Geography Department,

Barcelona, Spain

E-mail:anna.badia@uab.cat 
Jordi Duch

Autonomous University of Barcelona, Geography Department, Barcelona, Spain

E-mail: jordi.duch@uab.cat

\section{Notes}

[1] Between 1857 and 1860 three urban-planning projects to enlarge Barcelona were presented by Ildefons Cerdà i Sunyer in 1860, Miquel Garriga Roca between 1857 and 1858, and Antoni Rovira i Trias in 1859. The proposal presented by Rovira i Trias was chosen by the Barcelona City Government, whereas the proposal presented by Cerdà i Sunyer was chosen by the government of Madrid and signed by Queen Isabel II in 1860. Much controversy and opposition surrounded the approval and development of Cerdà's proposal. Political and social claims comprising low sustainable argumentation contradicted the plan. Changes in city hall, from a progressive to a conservative government, defended Rovira's Plan. Economic agents, mainly landowners, added their voice, being afraid of the effects of the plan's proclaimed low density. Cerdà's proposal went forward with some changes (García Melero, 1998).

${ }^{[2]}$ In addition to engineering, he developed military and political careers, both in Madrid and Barcelona. In 1851, he was elected progressive deputy for Barcelona's San Pedro district. In 1954 he was appointed sindico by the progressive city hall; and the regional deputy chief (Span. governador civil) appointed Ildefonso Cerdà as a municipal architect to start thinking about how to develop Barcelona.

${ }^{[3]}$ It is an accurate database of health, salary, family members, conditions and living standards of the working class.

[4] In 1933 the Catalan Architects and Technicians for the Implementation of Contemporary Architecture group (Cat. Grup d'Arquitectes i Tècnics Catalans per al Progrés de l'Arquitectura Contemporània) designed a plan that would later be known as El Pla Macià, referring to the first president of the Catalan government during that period. The plan revived Cerdà's design, adapting it to the new economic and demographic situation (Casellas, 2009). The 1992 Vila Olímpica Project followed Cerdà's grid.

${ }^{[5]}$ Sants, Sarrià, Sant Gervasi, Gràcia, Horta, Sant Andreu del Palomar and Sant Martí de Provençals.

${ }^{[6]}$ The neighbouring towns have been part of Barcelona since 1897.

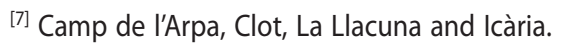

${ }^{[8]}$ This area corresponds to the built-up area, which differs from the total 1,969 hectares projected by Cerdà, which included streets and parks.

[9] "Manhattan or $L_{1}$ rectilinear": given a set of origin-destination points in the plane and a set of polygonal barriers to travel, the problem is to find the minimum rectilinear distance paths between given origin-destination points in the presence of polygonal barriers to travel (Larson \& Li, 1981).

\section{Acknowledgements}

This research was funded by the Spanish Ministry of Education, Science and Technology, and the Spanish Ministry of Science and
Innovation, Spain (project numbers: CSO2010-17178; B.O.E. Núm. 80, Jueves 2 de abril de 2009, Sec. III. Pág. 31721, Resolución 5562); and the Catalan Government, Quality Groups (project number 2009SGR0106). The authors are grateful to Wendy Guan of Harvard University, Institute of Quantitative Social Sciences, Center for Geographic Analysis (CGA), for her support and to Giovanni Zambotti, also from the CGA, for providing us technical support.

\section{References}

Aibar, E. \& Bijker, W. E. (1997) Constructing a city: The Cerda plan for the extension of Barcelona. Science, Technology, \& Human Values, 22(1), pp. 3-30. DOI: 10.1177/016224399702200101

Barcelona City Council (2011) Geoportal Barcelona. Barcelona: Mapa Parcel/lari. Available at: http://www.bcn.cat/geoportal (accessed 15 May 2011).

Bosque, J. \& Moreno, A. (eds) (2004) Sistemas de información geográfica y localización óptima de instalaciones y equipamientos. Madrid, RA-MA.

Busquets Grau, J. et al. (1992) Treballs sobre Cerdà i el seu eixample a Barcelona: Readings on Cerdà and the extension plan of Barcelona. Barcelona, Barcelona City Council, Spanish Ministry of Land and Public Infrastructures.

Carruthers, J. I. \& Ulfarsson, G. F. (2003) Urban sprawl and the cost of public services. Environment and Planning B: Planning and Design, 30(4), pp. 503-522. DOI: 10.1068/b12847

Cartographic Institute of Catalonia (2006) Base Topogràfica Nacional, 1:50.000. Barcelona.

Cartographic Institute of Catalonia (2010) Orthophoto of Catalonia. Barcelona.

Casellas, A. (2009) Barcelona's urban landscape. The historical making of a tourist product. Journal of Urban History, 35(6), pp. 815-832. DOI: $10.1177 / 0096144209339557$

Cerdà, I. (1849, 1854, 1859, 1860, 1861) (transcribed in 1991) Memoria del anteproyecto del ensanche de Barcelona. In: Ministry for Public Administration, Technical Secretariat \& Barcelona City Council (eds.) Teoría de la construcción de las ciudades aplicada al proyecto de reforma y ensanche de Barcelona por D. Ildefonso Cerdà ingeniero de caminos canales y puertos. Barcelona abril de 1859. Ildefonso Cerdá. Teoría de la construcción de las ciudades. Cerdà y Barcelona. Volume I. Teoría de la viabilidad urbana. Reforma de la de Madrid. Estudios hechos por el ingeniero D. Ildefonso Cerdà autorizado al efecto por RI. órden de 16 de Febrero de 1860. Cerdá y Madrid. Volume II. Madrid.

Cerdà, I. (1867) Teoría general de la urbanización y aplicación de sus principios y doctrinas a la reforma y ensanche de Barcelona. Madrid, Imprenta Española, Torija, 14, bajo.

Church, R. L. (1999) Location modelling and GIS. New York, John Wiley \& Sons.

Church, R. L. (2002) Geographical information system and location science. Computers \& Operations Research, 29(6), pp. 541-562. DOI: 10.1016/S0305-0548(99)00104-5

Church, R. L. \& Jankowski, P. (2008) Spatial optimization as a generative technique for sustainable multiobjective land-use allocation. International Journal of Geographical Information Science, 22(6), pp. 601-622. DOI: 10.1080/13658810701587495

Coates, B. E., Johnston, R. J. \& Knox, P. L. (1977) Geography and inequality. Oxford, Oxford University Press.

Conkling, E. C. \& Yeates, M. H. (1976) Man's economic environment. London, McGraw-Hill. 
Cox, K. L. (1979) Location and public problems: A political geography of the contemporary world. Chicago, Maaroufa Press.

Cromley, R. G. \& Hanink, D. M. (1999) Coupling land use allocation models with raster GIS. Journal of Geographical Systems, 1(2), pp. 137153. DOI: $10.1007 / \mathrm{s} 101090050009$

Davis, D. R. \& Weinstein, D. E. (2002) Bones, bombs and break points: The geography of economic activity. American Economic Review, 92(5), pp. 1269-1289. DOI: 10.1257/000282802762024502

De Blij, H. (2009) The power of place. Geography, destiny and globalization's rough landscape. New York, Oxford University Press.

Dicken, P. (1976) The multiplant business enterprise and geographical space: Some issues in the study of external control and regional development. Regional Studies, 10(4), pp. 401-412. DOI: 10.1080/09595237600185431

Estapé, F. (ed.) (1968-1971) Teoría general de la urbanización y aplicación de sus principios y doctrinas a la reforma del ensanche de Barcelona. Volumes I-III. Madrid, Institute of Fiscal Studies.

García Melero, J. E. (1998) Arte Español de la ilustración y del siglo XIX. En torno a la imagen del pasado. Madrid, Ediciones Encuentro.

Glaeser, E. (2011) Triumph of the city: How our greatest invention makes us richer, smarter, greener, healthier, and happier. New York, The Penguin Press.

Hakimi, S. L. (1964) Optimum locations of switching centers and the absolute centers and medians of a graph. Operations Research, 1964, 12(3), pp. 450-459. DOI: 10.1287/opre.12.3.450

Kamp, I., Leidelmeijer, K., Marsmanand, G. \& Hollander, A. (2003) Urban environment quality and human wellbeing: Towards a conceptual framework and demarcation of concepts; a literature study. Landscape and Urban Planning, 6(1-2), pp. 5-18. DOI: 10.1016/S01692046(02)00232-3

Krugman, P. (1998) Space: The final frontier. Journal of Economic Perspectives, 12(2), pp. 161-174. DOI: 10.1257/jep.12.2.161

Larson, R. C. \& Li, V. O. K. (1981) Finding minimum rectilinear distance paths in the presence of barriers. Networks, 11(3), pp. 285-304. DOI: 10.1002/net.3230110307

Le Galès, P. (2002) European cities: Social conflicts and governance. Oxford, Oxford University Press.

Levy, F. (2004) 11.202 Gateway: Planning economics. Typescript.

Ligmann-Zielinska, A. \& Jankowski, P. (2007) Agent-based models as laboratories for spatially explicit planning policies. Environment and Planning B: Planning and Design, 34(2), pp. 316-335. DOI: 10.1068/ b32088

Lloyd, P. E. \& Dicken, P. (1972) Location in space: A theoretical approach to economic geography. New York, Harper \& Row.

Malczewski, J. (1999) GIS and multicriteria decision analysis. New York, John Wiley \& Sons.

Moreno-Jimenéz, A. (1995) Planificación y gestión de servicios a la población desde la perspectiva territorial: algunas propuestas metodológicas 1. Boletín de la Asociación de Geógrafos Españoles, 20, pp. 115-134.

Narula, S. C., Ogbu, U. I. \& Samuelsoson, H. M. (1977) An algorithm for the P-Median problem. Operations Research, 25(4), pp. 709-713. DOI: $10.1287 /$ opre.25.4.709

National Geographic Institute $(1926,1951)$ Topographic documents fractionated in sheets (1st and 2nd edition), 1:50 000, numbers 420, 421. Madrid.

National Geographic Institute (1977) Topographic documents fractionated in sheets, 1:50 000, numbers 420, 421. Madrid.
Osleeb, J. \& Ratick, S. (1990) A dynamic location-allocation model for evaluating the spatial impacts for just-in-time planning. Geographical Analysis, 22(1), pp. 50-69. DOI: 10.1111/j.1538-4632.1990.tb00196.x

Pacione, M. (2003) Urban environmental quality and human well being - a social geographical perspective. Landscape and Urban Planning, 65(1-2), pp. 19-30. DOI: 10.1016/S0169-2046(02)00234-7

Pallares-Barbera, M. (1986) The p-median model and the location of schools in the Cerdà plan of expansion of Barcelona. Master's dissertation. Boston, Boston University, Department of Geography.

Pallares-Barbera, M. (2005) La percepció d'optimalitat en el pla Cerdà. El model P-median en el disseny ortogonal L1 de l'eixample de Barcelona. Treballs de la Societat Catalana de Geografia, 60, pp. 223-253.

Park, S. (1983) Aggregation effects and disaggregation of demand in location-allocation analyses. Discussion Paper no. 36. lowa City, University of lowa, Department of Geography.

Smith, D. M. (1973) The geography of social well-being in the United States: An introduction to territorial social indicators. New York, McGrawHill.

Smith, D. M. (1977) Human geography. A welfare approach. New York, St. Martin's Press.

Soja, E. (2010) Seeking spatial justice. Globalization and community. Minneapolis, University of Minnesota Press.

Solà-Morales Rubió, M. (1991) Cerdà urbanista. In: Ministry for Public Administration, Technical Secretariat \& Barcelona City Council (eds.) Teoría de la construcción de las ciudades. Cerdà y Barcelona, pp. 23-26. Madrid.

Soria y Puig, A. (1991) La obra de Cerdà a vista de pájaro. In: Ministry for Public Administration, Technical Secretariat \& Barcelona City Council (eds.) Teoría de la construcción de las ciudades aplicada al proyecto de reforma y ensanche de Barcelona por D. Ildefonso Cerdà Ingeniero de caminos canales y puertos. Barcelona abril de 1859. Ildefonso Cerdá. Teoría de la construcción de las ciudades. Cerdà y Barcelona. Volume I., pp. 17-22. Madrid.

Statistical Institute of Catalonia (2011) Barcelona: Evolució de la població de fet. Available at: http://www.idescat.cat (accessed 24 May 2011).

Tiebout, C. (1956) A pure theory of local expenditures. Journal of Political Economy, 64(5), pp. 416-424. DOI: 10.1086/257839

United Nations (2010) World population. Available at: http://www. un.org (accessed 20 Sept. 2010).

World Health Organization (2011) Part II: Global health indicators. Washington, DC. 